\title{
The Influence of Internal Factors on the Conventional Rural Banks Profitability in Indonesia Period 2015-2019
}

\author{
Eka Dasra Viana, Budi Purwanto, I Gusti Ngurah Ary Budi Hartawan \\ \{ekadasraviana@apps.ipb.ac.id, budipurwanto@apps.ipb.ac.id,ngurahari18@gmail.com\} \\ Departement of Management, Faculty of Economic and Management, IPB University \\ Jl. Agatis, IPB Dramaga Campus Bogor - West Java - Indonesia 16680
}

\begin{abstract}
During 2015-2019, the number of conventional rural banks in Indonesia decreased from 1637 to 1578 . This was followed by a decrease in profitability ratios which were proxied by Return on Assets (ROA). The decrease of profitability potentially endanger the continuity of rural banks business. This study aims to analyze the effect of internal factors consisting of capital, liquidity, efficiency, credit risk, and total assets of conventional rural banks on ROA. The data used is secondary data in the form of the financial ratio of 320 conventional rural banks in Indonesia in 2015-2019. This study uses panel data regression as analysis tool. The panel data regression results show that size (total assets) has a significant positive effect on ROA. Meanwhile, Operational Efficiency Ratio (BOPO) and Non-Performing Loan (NPL) have a significant negative effect on ROA. Capital Adequacy Ratio (CAR) and Loan to deposits Ratio (LDR) have no significant effect on ROA.
\end{abstract}

Keywords: Conventional Rural Banks, Internal factors, Panel data regression, Profitability.

\section{Introduction}

Rural banks is one of the banking institutions that plays an important role in improving the economy and banking institutions whose market segment is mostly for Micro, Small and Medium Enterprises (MSMEs). Rural Banks lending has proven to have a significant positive effect on regional economic improvement [1]. Rural Banks activities are attractive to MSMEs because of their faster and easier procedures than commercial banks [2].The main activities 
of Rural Banks consist credit and deposit. The following is data on Rural Banks activities in Indonesia for 2015-2019.

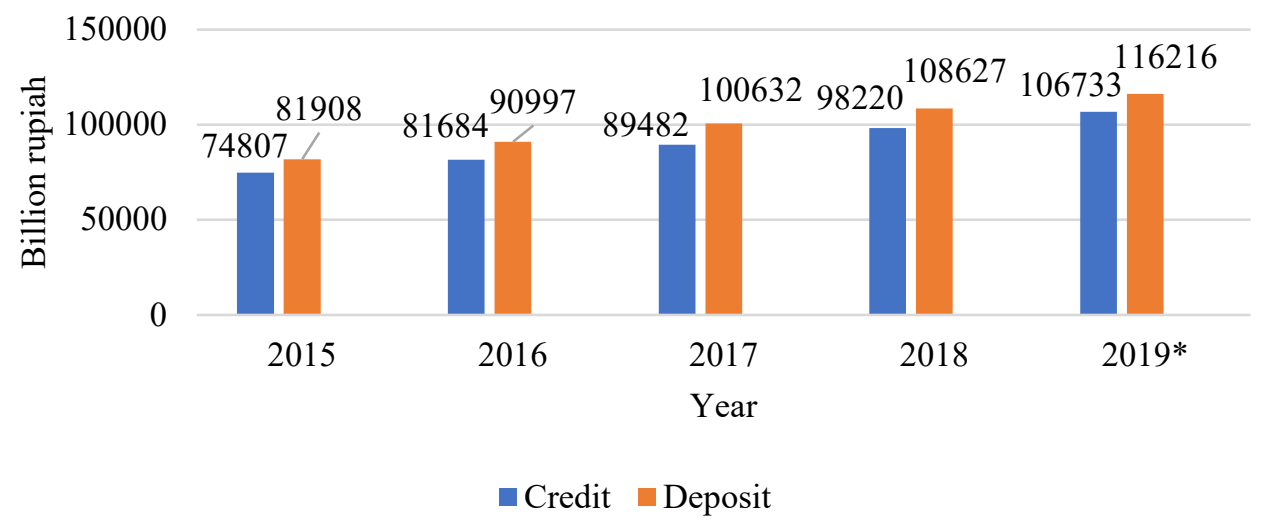

Figure 1. Credit and deposits conventional rural banks in Indonesia for 2015-2019

During 2015-2019, Rural Banks experienced an upward trend in their main function as financial intermediaries. This increase was indicated by an increase in credit distribution and collection of funds from the public. This illustrates that people are still interested in using rural banks services. In carrying out their activities, several rural banks experienced a decline in performance which resulted in a decrease in the number of rural banks in Indonesia by as many as 59 rural banks during 2015-2019. The following is data on the number of rural banks in Indonesia for 2015-2019.

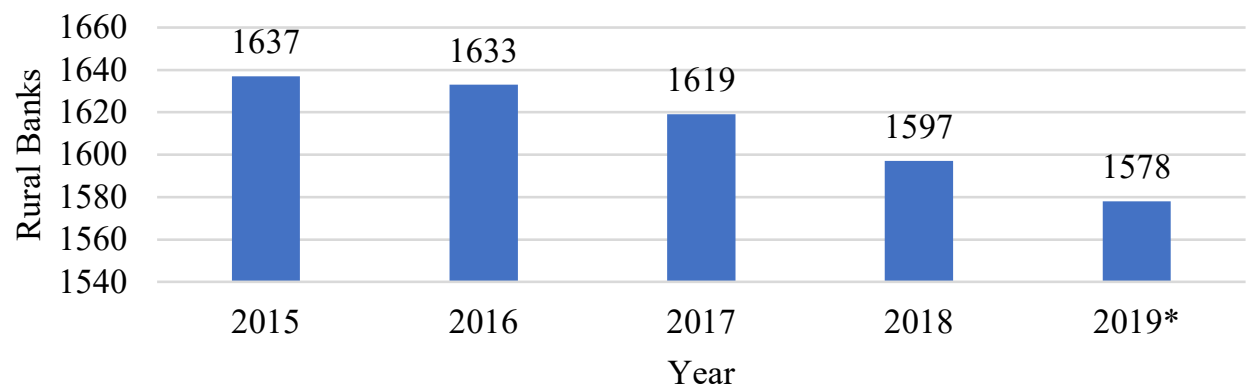

Figure 2. Number of rural banks in Indonesia for 2015-2019 
The decline in the number of conventional rural banks was largely due to liquidation. Lembaga Penjamin Simpanan (LPS) stated that rural banks were the most liquidated banks, as many as 31 rural banks during 2015 to September 2019 compared to 6 sharia rural banks and Commercial Banks that did not experience liquidation. Conventional rural banks liquidation is caused by the inability of Rural Bank to maintain financial health [3]. Letter of Bank Indonesia (BI) Number 30/12/KEP/DIR 1997 regarding the health of Rural Bank states that financial health can be viewed from the factor of profitability. The letter also mentions the profitability factor as measured by Return On Assets (ROA)[4]. The following is the development of ROA for Conventional Rural Banks 2015-2019.

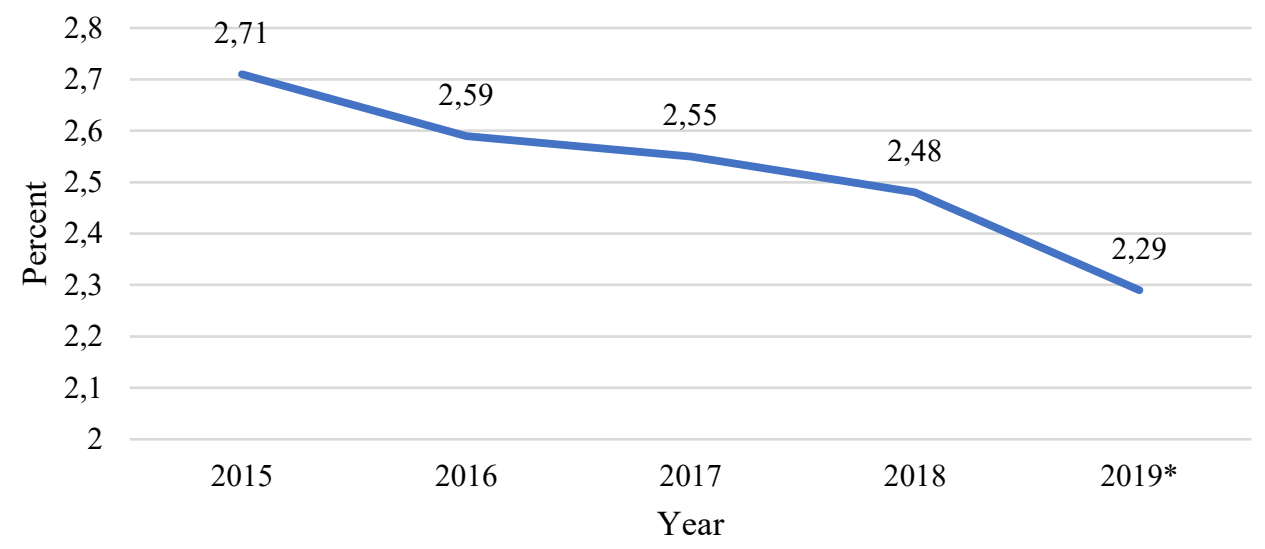

Figure 3. The development of roa for conventional rural banks 2015-2019

Figure 3 shows that the ROA of Conventional Rural Banks continued to decline during 2015-2019 although it was still in a healthy condition, namely above 1.215 percent. Declining profitability could potentially lead to rural banks liquidation. The decline in profitability, especially ROA, illustrates the decline in the ability of to use their assets for profit. The following is the data on the development of rural banks assets and profits during 2015-2019. 


\begin{tabular}{ccccc}
\hline Year & $\begin{array}{c}\text { Profit } \\
\text { (Billion } \\
\text { Rupiah) }\end{array}$ & Growth & $\begin{array}{c}\text { Assets (Billion } \\
\text { Rupiah) }\end{array}$ & Growth \\
\hline 2015 & 2755 & & 101713 & \\
2016 & 2936 & $0.066 \%$ & 113501 & $0,116 \%$ \\
2017 & 3210 & $0.093 \%$ & 125945 & $0,110 \%$ \\
2018 & 3371 & $0.050 \%$ & 135693 & $0,077 \%$ \\
$2019 *$ & 2484 & $-0.263 \%$ & 144779 & $0,067 \%$ \\
\hline
\end{tabular}

Assets of Rural Banks are important to review because most of the assets owned by banks are obtained from public savings [5]. In table 1 it can be seen that Rural Bank assets continue to increase while the profits received have increased in 2015-2018, but decreased in 2019. Even though profits had experienced a positive trend in 2015-2018, profit growth was still no greater than asset growth. Total assets can describe the size of a company. Alshatti [6] explain that size does not have a significant effect on ROA, which means that an increase in assets does not have a significant effect on profitability. This result occurred because of the addition of assets that did not contribute to the rural bank's efforts to increase profits. In contrast to the results of Alshatti (2016), Praja [7] found that the larger the size of the banking sector, which shows an increase in asset ownership, the bank can reach a wider market so as to generate greater profits. Apart from assets, decreased profitability also has an impact on the financial condition of rural banks [8]. The financial condition of rural banks can be seen in its financial ratios [9]. The following is data on the financial ratios of rural banks in Indonesia during 2015-2019.

Table 2. The financial ratios of rural banks in Indonesia during 2015-2019 


\begin{tabular}{ccccc}
\hline Tahun & CAR (\%) & LDR (\%) & BOPO (\%) & NPL (\%) \\
\hline 2015 & 30.96 & 77.81 & 143.29 & 5.37 \\
2016 & 25.10 & 76.24 & 88.96 & 5.83 \\
2017 & 35.83 & 75.36 & 101.55 & 6.15 \\
2018 & 36.86 & 76.54 & 91.82 & 6.37 \\
$2019 *$ & 36.10 & 77.81 & 102.03 & 7.34 \\
\hline
\end{tabular}

The capital aspect is reflected in the Capital Adequacy Ratio (CAR). The selection of CAR to describe capital is based on BI Letter Number 30/12 /KEP/ DIR 1997 concerning Rural Bank health. Table 2 shows a healthy CAR ratio because it is more than the minimum limit of 8 percent. This condition reflects that the Rural Bank nationally has sufficient capital for its operational activities. Adhim [10] obtains more capital which can cause banks to freely face the risk of loss. Different results were obtained by Ratnasari [8] who found that capital had a significant negative effect on profitability because too much capital could result in idle funds.

Apart from the capital factor, this study also analyzes the effect of liquidity on profitability. Loan to Deposit Ratio (LDR) can reflect the liquidity and intermediation function of Rural Banks. Table 2 shows that LDR decreased in 2015-2017, but increased again in 2018-2019. Even though it fluctuates, the LDR is in a healthy condition because the value is below 94.5 percent. This reflects that Rural Banks are not excessive in lending so that liquidity risk associated with withdrawal of third party funds is controlled. Ramadhani [11] found that an increase in LDR will increase ROA because more credit can increase income through credit interest. In contrast to the findings of Ramadhani [11], Wulandari [12] explains that LDR does not have a significant effect on ROA because an increase in the amount of excessive credit and not based on prudential principles will increase the risk of bad credit so that the credit does not provide profit and has the potential to cause losses.

Another factor that is thought to affect profitability is efficiency. The efficiency of a bank is indicated by the ratio of Operating Costs to Operating Income (BOPO). A healthy BOPO for Rural Bank is less than the same as 93.52 percent. The value of BOPO tends to fluctuate and experience unhealthy conditions in 2015, 2016 and 2019 (table 2). This condition reflects that the Rural Bank is not yet optimal in controlling its operations. Pandoyo [13] found that an increase in BOPO means an increase in operational costs which has the potential to reduce the operating profit of Rural Bank. Different results obtained by Hanifa [14], namely that BOPO has no effect on ROA. In this 
study, Rural Bank invested funds in non-operational aspects that could reduce operational losses.

The last factor that is thought to be related to profitability in the study is credit risk. Credit risk is important to analyze because banking in Indonesia mainly derives income from credit interest income [15]. Loans disbursed by Rural Banks are prone to experiencing non-performing loans, the amount of which can be seen in the Non-Performing Loans (NPL). Rural Bank NPLs during 2015-2019 continued to increase and were above the 5 percent healthy limit (table 2). Bank Indonesia Regulation Number 15/2/PBI/2013 states that a bank that has an NPL of more than 5 percent of total credit can endanger its business continuity [16]. Berliana [17] shows that the increased NPL value reflects the increasing number of non-performing loans that cannot be a profit for Rural Bank. Unlike Berliana [17], Sofyan's research [18] found that NPLs do not have a significant effect on ROA because losses due to non-performing loans can be borne by bank capital.

During 2015-2019, the number of conventional rural banks in Indonesia decreased from 1637 to 1578 . This was followed by a decrease in profitability ratios which were proxied by Return on Assets (ROA). The decrease of profitability potentially endanger the continuity of rural banks business. This study aims to analyze the effect of internal factors consisting of capital, liquidity, efficiency, credit risk, and total assets of conventional rural banks on ROA.

\section{Empirical Review}

Batten and Vo's [19] research entitled "Determinants of Bank Profitability - Evidence from Vietnam" examines the analysis of internal bank, banking industry and macroeconomic factors that affect the profitability of 35 commercial banks in Vietnam in 2006-2014. The background of this study is that the condition of bank profitability remained stagnant after the 2008 global financial crisis. In addition, minimal internal capital, high problem assets of 15 percent of the standard 4.7 percent, intense competition, and unfavorable macroeconomic conditions are thought to be the causes. stagnant banking profitability. This study discusses 3 factors to test their effects on profitability, namely bank internal factors, bank industry conditions, and market economy. 
Internal bank consists of bank size, capital adequacy, credit risk, cost, and productivity. The bank industry factor used is the market structure, while the macroeconomic factors used are inflation and Gross Domestic Product (GDP). One of the profitability ratios as the dependent variable is return on average assets (ROAA). This study uses an analysis tool in the form of panel data regression. The study found that ROAA is significantly negatively affected by bank size, cost and market structure, while capital adequacy is significantly and positively influenced by productivity. ROAA was found not to be influenced by credit risk, inflation, and GDP.

Saraswati's research [20] entitled "Analysis of Financial Performance Factors on the Profitability of Rural Banks" aims to analyze CAR, LDR, OER, and NPL which can affect ROA on 25 Rural Banks in Bandung City in 20142016. The research was conducted because the ROA of Rural Bank in Bandung City continued to decline from March 2014 to September 2016, even touching a negative number. The results of this study indicate that CAR and NPL have no effect on ROA. LDR and OER have a significant negative effect on ROA.

Menicucci and Paolucci's [21] research entitled "The Determinants of Bank Profitability: Empirical Evidence from European Banking Sector" examines internal bank factors that can affect the profitability of 35 European banks in 2009-2013. This research is motivated by the importance of profitability in microeconomics and macroeconomics. Microeconomically, profitability is an important aspect for banking in an effort to increase success in competition between other financial institutions. Meanwhile, on a macroeconomic basis, a profitable banking sector can contribute to maintaining financial stability in a country. Internal bank factors used include bank size, capital ratio, loan ratio, deposits and loan loss provisions. ROA is one of the profitability ratios as the dependent variable. Panel data regression method is an analytical tool used for data processing. Based on the research results, ROA is significantly influenced positively by bank size, capital ratio, and deposits, while the variable loan loss provisions has a negative and significant effect on ROA. Loan is a variable that has no real effect on ROA.

\section{Methodology}




\subsection{Data}

This study uses quantitative data sourced from secondary data. Secondary data were obtained from Rural Bank financial reports for 2015-2019 and Statistik Perbankan Indonesia (SPI) which were accessed through the official OJK website and other relevant literature. This research was conducted on 320 Rural Banks in Indonesia selected using the qouta sampling. The number of samples in each province can be seen in the following table.

Table 3. The number of samples in each province

\begin{tabular}{lccc}
\hline \multicolumn{1}{c}{ Province } & Population & Proportion(\%) & Number of Samples \\
\hline Aceh & 5 & 0.32 & 1 \\
Sumatera Utara & 54 & 3.42 & 11 \\
Sumatera Barat & 88 & 5.58 & 17 \\
Riau & 29 & 1.84 & 6 \\
Kepulauan Riau & 43 & 2.72 & 9 \\
Jambi & 19 & 1.20 & 4 \\
Bengkulu & 5 & 0.32 & 1 \\
Sumatera Selatan & 24 & 1.52 & 5 \\
Kepulauan Bangka Belitung & 4 & 0.25 & 1 \\
Lampung & 25 & 1.58 & 5 \\
Banten & 58 & 3.68 & 12 \\
Jawa Barat & 274 & 17.36 & 55 \\
DKI Jakarta & 23 & 1.46 & 4 \\
Jawa Tengah & 252 & 15.97 & 51 \\
DI Yogyakarta & 53 & 3.36 & 11 \\
Jawa Timur & 293 & 18.57 & 59 \\
Bali & 133 & 8.43 & 27
\end{tabular}




\begin{tabular}{lccc}
\hline \multicolumn{1}{c}{ Province } & Population & Proportion(\%) & Number of Samples \\
\hline Nusa Tenggara Barat & 29 & 1.84 & 6 \\
Nusa Tenggara Timur & 12 & 0.76 & 2 \\
Kalimantan Utara & 0 & 0.00 & 0 \\
Kalimantan Barat & 21 & 1.33 & 4 \\
Kalimantan Tengah & 6 & 0.38 & 1 \\
Kalimantan Timur & 15 & 0.95 & 3 \\
Kalimantan Selatan & 26 & 1.65 & 5 \\
Gorontalo & 4 & 0.25 & 1 \\
Sulawesi Utara & 18 & 1.14 & 4 \\
Sulawesi Barat & 1 & 0.06 & 1 \\
Sulawesi Tengah & 8 & 0.51 & 2 \\
Sulawesi Selatan & 23 & 1.46 & 5 \\
Sulawesi Tenggara & 16 & 1.01 & 3 \\
Maluku Utara & 3 & 0.19 & 1 \\
Maluku & 2 & 0.13 & 1 \\
Papua & 7 & 0.44 & 1 \\
Papua Barat & 5 & 0.32 & 320 \\
\hline \multicolumn{1}{c}{ Total } & 1578 & 100 & 1 \\
\hline
\end{tabular}

\subsection{Variable Definition}

The research variables used are Capital Adequacy Ratio (CAR), Loan to Deposit Ratio (LDR), Operating Expenses, Operating Income (BOPO), Non Performing Loans (NPL), and Rural Bank Size as independent variables and the dependent variable is Return on Assets (ROA). The explanation regarding all variables is presented in the following table.

Table 4. Variable Definition 


\begin{tabular}{|c|c|c|}
\hline No & Variable & Equation \\
\hline 1 & $\begin{array}{l}\text { Capital Adequacy Ratio (CAR) } \\
\text { [22] }\end{array}$ & $\mathrm{CAR}=\frac{\text { Capital }}{\text { Risk Weight Assets }} \times 100(1)$ \\
\hline 2 & $\begin{array}{l}\text { Loan to Deposit Ratio (LDR) } \\
\text { [23] }\end{array}$ & $\mathrm{LDR}=\frac{\text { Total Credit }}{\text { Third Party Funds }} \times 100(2)$ \\
\hline 3 & $\begin{array}{l}\text { Operating Expenses Operating } \\
\text { Income (BOPO) } \\
{[24]}\end{array}$ & $\mathrm{BOPO}=\frac{\text { Operating Expenses }}{\text { Operating Income }} \times 100(3)$ \\
\hline 4 & $\begin{array}{l}\text { Non Performing Loan (NPL) } \\
\text { [24] }\end{array}$ & $\mathrm{NPL}=\frac{\text { the number of problem loans }}{\text { total credit }} \times 100(4)$ \\
\hline 5 & $\begin{array}{l}\text { Size } \\
{[25]}\end{array}$ & Size $=\ln ($ total asset) $(5)$ \\
\hline 6 & $\begin{array}{l}\text { Return on Assets (ROA) } \\
{[24]}\end{array}$ & $\mathrm{ROA}=\frac{\text { Earning Before Tax }}{\text { Average Total Asset }} \times 100(6)$ \\
\hline
\end{tabular}

\subsection{Research hypotheses}

The hypotheses to be tested are :

H1 : CAR have a positive effect on ROA

H2 : LDR has a positive effect on ROA

H3 : BOPO has a negative effect on ROA

H4 : NPL has a negative effect on ROA

H5 : Size has a positive effect on ROA 


\subsection{Method of analysis}

Data processing method using panel data regression method. Panel data regression was chosen because the data used is a combination of cross section data and time series data. Panel data regression consists of 3 data processing stages consisting of selecting a panel data regression model, classical assumption testing, and hypothesis testing resulting in a panel data regression equation as follows :

ROAi, $=\alpha+\beta 1$ CARi, $t+\beta 2$ LDRi, $t+\beta 3$ BOPOi, $t+\beta 4$ NPLi, $t+\beta 5$ Sizei, $t+\varepsilon i t(7)$

Where :

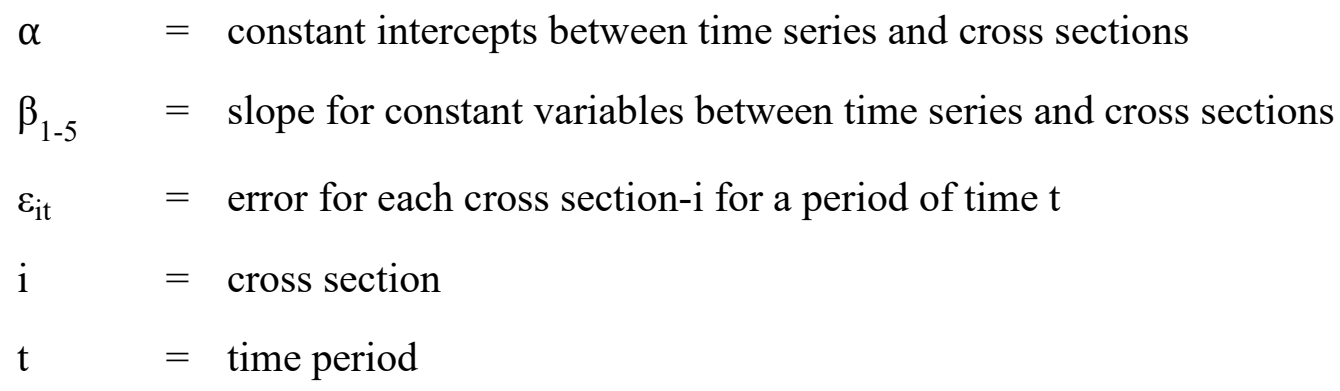

\section{Result and Discussion}

\subsection{Financial Condition of Sample Rural Bank}

Financial ratios are description of a company's financial condition. Financial ratios can also be considered by managers in making decisions. This study uses 5 financial ratios, namely CAR, LDR, BOPO, and NPL as independent variables and ROA as the dependent variable. In addition to financial ratios, this study also analyzes the condition of total assets of rural banks which are analyzed by size. The following is the development of the financial conditions of the 320 Rural Banks used as samples from 2015-2019. 
The ROA condition in the sample of Rural Banks during 2015-2019 tended to increase during 2016 but the next trend decreased even though it was still in the healthy category, equal to or above 1.215 percent. In 2015, 67 samples of rural banks were not included in the healthy category. In 2016 and 2017 there were 81 Rural Banks. In 2018 it was 94 and up to September 2019 it was 103. This decline shows that Rural Banks have not been able to optimally utilize investment returns on assets to obtain or increase profits.

Tabel 5. Financial conditions of 320 Rural Bank

\begin{tabular}{ccccccc}
\hline \multirow{2}{*}{ No } & Variable & \multicolumn{5}{c}{ Year } \\
\cline { 3 - 7 } & & 2015 & 2016 & 2017 & 2018 & $2019^{*}$ \\
\hline 1. & ROA & 2.94 & 3.03 & 2.84 & 2.3 & 2.14 \\
2. & CAR & 28.17 & 29.79 & 32.05 & 31.61 & 29.6 \\
3. & LDR & 80.63 & 77.77 & 75.54 & 75.98 & 79 \\
4. & BOPO & 89.39 & 89 & 88.14 & 89.89 & 96.22 \\
5. & NPL & 6.23 & 6.9 & 7.48 & 8.05 & 8.62 \\
6. & Size & 17.16 & 17.27 & 17.38 & 17.46 & 17.52 \\
\hline
\end{tabular}

The CAR value has increased from 2015-2017 but decreased in 2018-2019 (Table 5). CAR is a financial ratio that reflects the capital owned by the Rural Bank by taking into account the risk aspects of an asset. In aggregate, the sample of Rural Banks used has exceeded the minimum CAR limit for a Rural Bank, which is 8 percent. This shows that Rural Banks have large capital to run operations and bear risks for their operations.

The LDR value in the 320 sample Rural Banks tends to fluctuate because of the decline in development in 2015-2017 but increased in 2018-2019 (table 5). Rural Bank LDR is in a healthy condition because the value is below 94.75 percent. The decrease in LDR in 2015-2017 was caused by an increase in the collection of funds but not accompanied by loan disbursement. This condition 
reflects that Rural Banks have not optimally utilized third party funds to be channeled into credit.

The value of BOPO is experiencing a good trend because it had decreased in 2015-2017 but increased again in 2018 and was even in an unhealthy condition in 2019 (table 5). BOPO Rural Bank is in an unhealthy condition in 2019 because its value exceeds 93.52 percent. An unhealthy condition of Rural Bank operational efficiency can disrupt a bank's ability to earn profits. This is due to the increasing operational costs at a bank and not accompanied by operating income.

The NPL development in the sample of Rural Banks was classified as poor because it continued to increase during 2015-2019 (table 5). The increase in NPL occurred until it was in an unhealthy condition which was determined by the OJK at 5 percent. This condition shows that non-performing loans are very vulnerable to occur in Rural Banks. This could disrupt the profitability of the Rural Bank, considering that the main income of the Rural Bank comes from credit payments by customers.

Apart from using the financial ratio aspect, this study also tries to analyze the effect of Rural Bank size on Rural Bank profitability. The size of the Rural Bank is a reflection of the total assets owned by the Rural Bank. Table 5 shows the average size of Rural Banks continued to increase during 2015-2019. Throughout 2015-2019, the sample of Rural Banks that had the smallest rural bank size was Abang Pasar with a size of 12.72 or assets of 335.9 million rupiah. Eka Bumi Artha is the largest sample of Rural Banks with a size of 22.86 or assets of 8.5 billion rupiah.

\subsection{Empirical Result}

\subsubsection{Panel Data Regression Model Selection}

There are three models used to estimate panel data regression, namely the Common Effect Model, Fixed Effects Model, and the Random Effects Model [26]. The model selection is done through 3 tests with a significance level of 0.05 , namely the Chow test, Hausman test and Lagrange Multiplier test. The Chow test is useful for making the best choice between FEM or CEM. The 
Hausman test is carried out to decide between FEM or REM while the Lagrange Multiplier test is useful for confirming the model between REM or CEM used in panel data.

Model selection starts with the Chow Test then continues with the Hausman Test. Based on the Chow test, the chi-square p-value is 0.0000 , which means that the currently selected model is the Fixed Effect Model (FEM). Based on the Hausman test, the chi-square probability is 0.0000 which means that FEM is the best model.

\subsubsection{Classic assumption test}

The classical assumption test on panel data regression serves to ensure that the regression results obtained are free from normality, multicollinearity, heteroscedasticity, and autocorrelation. Pallant [27] states that studies with a large sample of more than 40 samples can ignore the problem of normality because a large sample can follow the population distribution. Apart from the normality test, the autocorrelation test does not need to be done when the selected model is a fixed effect [28]. The following are the results of the classic assumption test.

\section{Multicollinearity Test}

Widarjono [26] states that if the positive or negative correlation value between independent variables is more than 0.85 , there will be a multicollinearity problem in the model. Table 6 shows that the correlation value between the independent variables is not more than 0.85 so that this model does not experience multicollinearity.

Table 6. Multicollinearity Test

\begin{tabular}{cccccc}
\hline & CAR & LDR & BOPO & NPL & Size \\
\hline CAR & 1.000000 & -0.241201 & 0.004677 & 0.032303 & -0.336497 \\
LDR & -0.241201 & 1.000000 & 0.115849 & 0.027483 & -0.033593 \\
BOPO & 0.004677 & 0.115849 & 1.000000 & 0.258514 & -0.291687
\end{tabular}


NPL

$$
0.032303 \quad 0.027483
$$

\section{Heteroscedasticity test}

Heteroscedasticity testing used the Glejser test. The Glejser test is carried out by testing the effect of independent variables on the absolute residual value. The criteria used to declare the absence of heteroscedasticity the p-value must be greater than 0.05 . The results of the Glejser test stated that the selected model did not experience heteroscedasticity because the regression p-value of each independent variable on the absolute residual was greater than 0.05 percent (Table 7).

\begin{tabular}{|c|c|}
\hline Variable & P-Value \\
\hline CAR & 0.9884 \\
\hline LDR & 0.1276 \\
\hline BOPO & 0.6276 \\
\hline NPL & 0.5278 \\
\hline Size & 0.2085 \\
\hline
\end{tabular}

Table 7. Heteroscedasticity test

\subsubsection{Hypothesis test}

The final step in panel data regression analysis is hypothesis testing. Hypothesis testing includes the coefficient of determination $\left(\mathrm{R}^{2}\right)$, simultaneous test and partial test.

The coefficient of determination test can be seen from the amount of Adjusted R-Squared at the FEM output. The Adjusted R-Squared value shown in the attachment is 0.561327 or 56.13 percent. This value shows that the ability of the independent variables to be able to explain the ROA variable is 
56.13 percent while the remaining 43.87 percent is explained by other variables that are not present in this study.

Simultaneous test is useful for ensuring the independent variable simultaneously affects the dependent variable. This research model obtained a probability value F-statistic of 0.000000 . The probability value of F-statistic explains that the independent variable can simultaneously influence the dependent variable.

The $t$ statistical test aims to measure the size and significance of the effect of the independent variables partially on the dependent variable. In the study, the $\alpha$ value used was 0.05 . The following is a table of the results of the $t$ statistical test.

Table 8. t statistical test

\begin{tabular}{lcc}
\hline Variable & Coefficient & P-Value \\
\hline C & -25.19710 & 0.0003 \\
CAR & 0.008106 & 0.4502 \\
LDR & 0.005924 & 0.3470 \\
BOPO & -0.063115 & 0.0000 \\
NPL & -0.085258 & 0.0001 \\
Size & 1.929437 & 0.0000 \\
\hline
\end{tabular}

\subsection{The effect of CAR on ROA}

CAR has a regression coefficient of 0.008106 and a p-value of 0.4502 . These results state that hypothesis one is rejected. Rejection of hypothesis 1 means that CAR does not significantly affect ROA. The increase in capital did not have a significant impact on increasing profitability. During 2015-2019, 
RURAL BANK capital, especially CAR, had a large value far from the healthy value set at only $8 \%$. Capital, especially the high CAR value, indicates that Rural Banks have not optimally utilized their capital for lending activities and investment in rural banking business development. Its large value also indicates the amount of idle capital and is only used to prevent losses due to assets that have risk. This research is in accordance with the findings of Saraswati [20] although it is different from the findings of Adhim [10] which states that greater capital can increase profitability and Ratnasari's research [8] which found that increased capital has a decreasing impact on profitability.

\subsection{The effect of LDR on ROA}

The estimation results show that the LDR variable produces a coefficient of 0.005924 and a probability of 0.3470 . This value rejects hypothesis two. This concludes that LDR does not significantly affect ROA.

The increase in liquidity was not significant for the increase in Rural Bank profitability. This condition is due to the high NPL value of Rural Banks, which means that Rural Bank lending has not been supported by good credit quality. In addition, the increase in excessive lending, especially more than 100 percent, uses funds other than third parties or RURAL BANK customers that can be sourced from capital or related party funds (linkage program). Both capital and funds sourced from linkage programs have a higher cost than public funds, causing the potential to reduce RURAL BANK profits. This result is in line with the research of Wulandari [12] which states that the higher the liquidity is, the profitability does not necessarily increase. The results of this study contradict and Ramadhani [11] .

\subsection{The effect of BOPO on ROA}

The results of panel data processing obtained the BOPO coefficient and probability, namely -0.063115 and 0.0000 . This proves that BOPO has a 
significant negative effect on ROA. An increase in BOPO of 1 percent will cause a decrease in ROA of 0.063115 .

A larger BOPO indicates that RURAL BANK's operational efficiency is getting worse. The results of the study are in accordance with the findings of Pandoyo [13] which explains that the greater the value of BOPO, the increase in operating costs is greater than the increase in operating income, so the bank's profit will decrease. This study contradicts the research of Hanifa[14] which explains that RURAL BANK in his research has been able to invest funds optimally in the non-operational aspect so as to reduce operational losses.

\subsection{The effect of NPL on ROA}

NPL obtained a coefficient of -0.085258 and probability of 0.0001 . These results indicate the fourth hypothesis is accepted, which means that NPL has a significant negative effect on ROA. An increase in NPL of 1 percent will reduce ROA by 0.085258 .

A larger NPL value reflects an increase in non-performing loans that is borne by a RURAL BANK. The results of the study are in accordance with Berliana [17] and Taqiyya [15] which show non-performing loans can cause Rural Banks to lose their main income which comes from loan interest income. This research is different from the findings of Sofyan [18] that obtaining NPL does not have a significant effect on ROA because losses due to bad credit are borne by the capital owned by the bank.

\subsection{The effect of Size on ROA}

The variable of RURAL BANK size obtained a coefficient value of 1.929437 and a probability of 0.0000 . These results explain that the size of the RURAL BANK has a significant positive effect on ROA. Gujarati [28] states that in a linear-log model an increase in $\mathrm{x}$ by one percent will increase $\mathrm{Y}$ by 0.01 multiplied by the slope $(\beta)$ of the variable. The variable of Rural Bank size 
reflects the total assets owned by the Rural Bank. A 1 percent increase in total assets will lead to a 0.019 percent increase in ROA.

The increase in Rural Bank assets resulted in increased profitability achieved by Rural Banks. This research is in line with the findings of Praja [7] and Menicucci [21].This is because large assets provide opportunities for Rural Banks to access a wider market and diversify products in order to reduce risks that cause losses for Rural Banks. This research contradicts the findings of Batten [19] who found that the banks studied were in a diseconomies scale, namely an increase in the scale of operations followed by bureaucracy, high wages, and inefficient operations.

\section{Conclusion and Implications}

The results of this study indicate that Rural Bank size affects Rural Bank ROA in a significant positive manner. ROA of Rural Bank is also significantly negatively affected by BOPO and NPL. Meanwhile, CAR and LDR do not significantly affect ROA. Managerial implications that can be done to increase ROA according to the results obtained include:

1.BOPO relates to operational inefficiency. Increasing inefficiency will reduce profitability. Inefficiency can be reduced by reducing operating costs and increasing operating income. Reduction of operational costs can be done by eliminating operational activities that do not generate profits. Increased income can be obtained through fee-based income, namely income outside of credit.

2.NPL has a significant negative effect while LDR does not significantly affect ROA. This proves that improving credit quality is more important than increasing the amount channeled to increase profits. Credit quality improvement to reduce non-performing loans can be done in 2 ways, namely the application of the principle of providing credit and salvaging nonperforming loans.

3. Rural Bank size has a significant positive effect while CAR does not significantly influence ROA. Rural Bank capital should be used to increase Rural Bank assets but still pay attention to the healthy condition of the CAR, which is $8 \%$. Management can increase company assets that focus on developing Rural Bank businesses in order to achieve economies of scale. In 
addition, the large size of the Rural Banks allows Rural Banks to undertake economies of scope to diversify investment in assets and service products so as to reduce the risk of loss.

This study has not been able to prove that liquidity, especially LDR and capital, especially CAR, has a significant effect on profitability. Future research can further examine the effect on capital, especially CAR and liquidity, especially LDR, which cannot be explained in this study. Subsequent research can also adjust the research to the new OJK regulations regarding RURAL BANK if there are regulatory updates.

\section{Author Contributions}

All author contributed to conceive the study and all author certify that have participated sufficiently in the work to take public responsibility for the contents, including participation in the concept, design, and analysis, writing, or revision of the manuscript.

Acknowledgments. We thank the IPB University for supporting this research

\section{References}

[1] Supartoyo YH. Peran Bank Perkreditan Rakyat terhadap Perekonomian Regional dan Kesejahteraan Masyarakat di Wilayah Sulawesi. IPB University. 2018

[2] Herli AS. Buku Pintar Pengelolaan RURAL BANK dan Lembaga Keuangan Pembiayaan Mikro. Yogyakarta (ID): Andi. 2013

a. Mahya NY. Pencabutan izin usaha dan likuidasi bank. Jurnal dan Pendidikan Ilmu Sosial. 2020. 4(1): 284-289

[3] Bank Indonesia. Surat Direksi Bank Indonesia Nomor 30/12/KEP/DIR 1997 tentang Tatacara Penilaian Tingkat Kesehatan Bank Perkreditan Rakyat. Available at: https://zinsari.files.wordpress.com/2018/10/sk-dir-tks-Rural bank.pdf

[4] Taqiyya T.H. Analisis Determinan Profitabilitas Bank Go Public di Indonesia Setelah Krisis Tahun 2008: Faktor Internal dan Eksternal. IPB University. 2017

[5] Alshatti AS. Determinants of banks' profitability - the case of Jordan. Investment Management and Financial Innovations. 2016. 13(1): 84-91 
[6] Praja NBA, Hartono U. Pengaruh ukuran perusahaan, capital adequacy ratio, loan to deposit ratio, dan non performing loan terhadap profitabilitas bank umum swasta nasional devisa yang terdaftar di Indonesia periode 2012-2016. Jurnal Ilmu Manajemen

[7] Ratnasari F. Analisis Faktor Internal yang Memengaruhi Profitabilitas Bank Perkreditan Rakyat Konvensional di Riau Periode 2014-2016. IPB University. 2017

[8] Hery. Analisis Laporan Keuangan Integrated and Comprehensive Edition. Jakarta (ID): Grasindo. 2017

[9] Adhim C. Pengaruh Risiko Kredit, Risiko Likuiditas, dan Efisiensi Manajemen terhadap Profitabilitas melalui Permodalan (Studi Kasus pada Perbankan yang Terdaftar di Bursa Efek Indonesia). Universitas Brawijaya. 2017

[10] Ramadhani P. Pengaruh Faktor Internal dan Eksternal Bank terhadap Profitabilitas Sembilan Bank Terbesar di Kawasan Asean. IPB University. 2019

[11] Wulandari. Pengaruh Rasio CAMEL terhadap Profitabilitas (ROA) Perusahaan Perbankan yang Terdaftar di Bursa Efek Indonesia Periode 2013-2015. Universitas Negeri Yogyakarta. 2018

[12] Pandoyo. Faktor-faktor yang memengaruhi profitabilitas bank Rural bank di provinsi Jawa Barat. Jurnal Riset Manajemen dan Bisnis (JRMB) Fakultas Ekonomi UNIAT. 2019. 4(1): $127-136$

[13] Hanifa R, Trianto A, Hendrich M. Determinan profitabilitas bank perkreditan rakyat di kota palembang periode 2013-2018. Management, Business, and Accounting (MBIA). 2019. 18(3): $73-89$

[14] Silitonga RI. Determinan Non Performing Loan terhadap Return On Asset Pada Perusahaan Perbankan Terbuka di Indonesia. Universitas Sumatera Utara. 2020

[15] Bank Indonesia. Peraturan Bank Indonesia Nomor 15/2/PBI/2013 tentang Peraturan Bank Indonesia Nomor 15/2/PBI/2013 tentang Penetapan Status dan Tindak Lanjut Pengawasan Bank Umum Konvensional Available at: https://www.bi.go.id/id/peraturan/perbankan/Pages/PBI_15_2_PBI_2013.aspx

[16] Berliana IM. Analisis Pengaruh Risiko Kredit, Likuiditas, Tingkat Kecukupan Modal, dan Perputaran Kas Terhadap Profitabilitas Perusahaan Perbankan yang Terdaftar Di BEI. Universitas Negeri Yogyakarta. 2019

[17] Sofyan M. Faktor-faktor yang mempengaruhi profitabilitas bank perkreditan rakyat (Rural bank) di Provinsi Jawa Timur. Jurnal Inspirasi Bisnis dan Manajemen. 2019. 3(1):63-76

[18] Batten J, Vo XV. Determinants of bank profitability—evidence from Vietnam. Emerging Markets Finance and Trade. 2019. 55(6): 1417-1428

[19] Saraswati AD.Analisis Faktor Kinerja Keuangan terhadap Profitabilitas Bank Perkreditan. IPB University. 2017 
[20] Menicucci, E., Paolucci, G. The determinants of bank profitability: empirical evidence from European banking sector. Journal of Financial Reporting and Accounting. 14(1): 86115. 2016

[21] Dendawijaya L. Manajemen Perbankan Edisi Kedua. Bogor (ID): Ghalia Indonesia. 2005

[22] Budisantoso T, Nuritomo. Bank dan Lembaga Keuangan Lain. Jakarta (ID): Salemba Empat. 2014

[23] Taswan. Manajemen Perbankan Konsep, Teknik \& Aplikasi. Yogyakarta (ID): UPP STIM YKP. 2010

[24] Riyanto B. Dasar-dasar Pembelanjaan Perusahaan. Yogyakarta (ID): Penerbit BPFE. 2008

[25] Widarjono A. Ekonometrika Pengantar dan Aplikasinya Dilengkapi Aplikasi Eviews Yogyakarta (ID): Ekonisia. 2009.

[26] Pallant, J. SPSS Survival Manual, A Step By Step Guide To Data Analysis Using SPSS For Windows Third Edition. Sydney (AU): McGraw Hill. 2007

[27] Gujarati, D. Ekonometri Dasar. Sumarno Z (translator). Jakarta (ID): Erlangga. 2003.

[28] Otoritas Jasa Keuangan. Statistik Perbankan Indonesia September 2019. Available at: https://www.ojk.go.id/id/kanal/perbankan/data-dan-statistik/statistik-perbankanindonesia/Pages/Statistik-Perbankan-Indonesia---September-2019.aspx 